\title{
Is There a Neglected Firm Effect?
}

\author{
Steven A. Carvell \\ Cornell University \\ Paul J. Strebel \\ IMEDE
}

Empirical exceptions to the Capital Asset Pricing Model's description of security returns frequently have been presented as special effects: the P/E effect, the small firm effect, the January effect, the neglected firm effect, and the listing effect, Ball (1978), Basu (1977), Banz (1978), Reinganum (1981), Keim (1982), Arbel and Strebel (1982) and Barry and Brown (1984). An interesting question is whether these effects are indeed separate, or whether they are all manifestations of the same phenomenon? Banz (1978), for example, argues that the small firm effect statistically dominates the $\mathrm{P} / \mathrm{E}$ anomaly. Arbel and Strebel point out that most small firms are neglected, while Barry and Brown (1984) observe that most firms have been listed for shorter periods than large firms. Finally, Keim (1982) finds that almost 50 percent of the annual returns on small capitalization securities occur in January, with much poorer performance during the rest of the year

One explanation of the small firm effect is based on tax loss selling: small capitalization securities, being those with the highest probability of capital loss during the year, due to the high variance in their return distributions, are sold in December to realize the losses. This tax-induced process artificially depresses the price of the stock. In January, the price is then bid back up to its pretax loss selling equilibrium level, thereby generating the high January returns on small firms, Roll (1983).

On the other hand, a conceptually separate explanation has been put forward for the neglected firm and listing effects, having to do with 'differential' information: securities neglected by analysts, or listed for a short period of time, potentially sell at a discount owing to the relative lack of information about their future return distributions. Conversely, intensive analysts' coverage and long listing periods increase the information available to investors when projecting future return distributions, correspondingly raising the prices and lowering the return on highly followed firms. If this explanation holds, then it implies firstly, more than one fundamental reason behind the abnormal return effects, and secondly, that the neglected firm effect should be empirically distinct from the small firm and January effects. 
The objective of this paper is to examine the statistical basis of the neglected firm effect: whether it is indeed statistically distinct from the small firm and January effects or not. Relative to previous work on neglected securities, the results reported are obtained from the use of superior data bases and a more rigorous statistical analysis. The paper proceeds with sections on data and statistical methodology, and an analysis of the neglected firm effect.

\section{Data and Statistical Methodology}

The data used in this study came from two sources. First, the research coverage of securities by analysts was obtained from the IBES (Institutional Brokers Estimate Survey) data base provided by Lynch, Jones and Ryan, a New York brokerage firm. The data base consists of 79 months of data from January 1976 through July 1982 for approximately 2000 companies per year. This data base provided monthly data on the number of analysts making predictions of future earnings, the mean forecast and its standard deviation, for all companies in the study. These statistics come from canvassing over 1200 analysts nationwide and combining their estimates to obtain the mean and the standard deviation of the analysts' forecasts on each security. The IBES tape covers a broad crosssection of securities and includes all companies for which an analyst makes a projection.

The second source of return and market capitalization data for each security was obtained from the CRSP (Center for Research in Security Prices) monthly return files. The CRSP files are unique in that securities delisted from the exchange are not delisted from the data base. This is desirable for a database employed to study neglected securities since it precludes the bias associated with the potentially greater likelihood of delisting among neglected securities.

Given the IBES and CRSP tapes, the sample used in the study comprised 865 stocks with data available on both tapes. Although the CRSP data restricted the sample to NYSE securities, this subset contains a sufficient range of analyst attention across stocks to test for the existence of an abnormal return effect associated with neglected stocks. The study was limited to the 72 month period common to both the CRSP and IBES tapes, covering January 1976 through December 1981. The risk free rate chosen for the study was the monthly return from ninety-day Treasury Bills. I 
The value weighted Wilshire 5000 index was employed as the 'market' in this study in order to leave intact as much of the small firm effect as possible, and permit an examination of its interaction with the neglected firm effect, to the extent that the latter exists.' In addition, the value weighted index has the advantage of having a stronger theoretical base in the CAPM, which was used as the point of departure for the measurement of excess returns.

Monthly rather than daily or weekly returns were used to avoid the risk measurement problems generated by shorter period returns on thinly traded securities, Roll (1981), which were more likely to have been neglected firms than highly followed firms. The betas were estimated for each month of the test period using a 60 month moving window: for example, the January 1976 beta as calculated using data from January 1971 through December 1975. If the five full years of data was not available, beta calculations employed a minimum of three years of data. As a result, all securities with under three years of listing were eliminated from the sample. The sample bias introduced by this approach is discussed by Barry and Brown (1984). The procedure, however, is common in the finance literature and is generally acceptable as a methodology of beta calculation.

The explanatory first test for the neglected firm effect followed Banz's (1978) approach to the $\mathrm{P} / \mathrm{E}$ anomaly. Following Banz, the sample was separated into three approximately equally sized portfolios based on the number of analysts' reporting EPS estimates for each stock. The portfolios were reformed each month to ensure that each portfolio contained only securities with the appropriate level of analysts' attention. Next, the average monthly returns and excess risk adjusted returns were computed for each portfolio across the sample period. To control for size, the procedures were repeated for three categories of market value, which produced nine iso-neglect, iso-size portfolios for comparative analysis. To avoid confusing a neglected firm effect with the January effect, the tests were repeated after eliminating January returns from the sample.

Second, the more rigorous, and methodologically independent, test for the neglected firm effect employed the two step procedure of Fama and Macbeth (1973). These tests were also repeated after eliminating January returns. 


\section{Analysis of the Neglected Firm Effect}

The average monthly returns over the test period for the highly researched, moderately researched, and neglected portfolios are shown in Table 1. Research concentration ranking one (RCRI) contained only highly researched stocks with more than eight analysts covering them. This group had an average monthly return of 0.011 compared to average monthly returns of 0.024 in the neglected portfolio (RCRS) where fewer than three analysts provided forecasts of corporate earnings. Moderately researched stocks had average monthly returns of 0.017 , higher than the highly researched portfolio and less than the neglected portfolio.

But Table 1 also suggests two important correlations: first, the average market value of the securities in each portfolio declined with the degree of neglect (the number of analysts); second, the average beta increased with neglect. Table 2 contains the results of an examination of these correlations, listing the average coefficients from a cross-sectional monthly regression of beta $(p)$ and log-size on the number of analysts (NA) following each stock in the sample. Log-size was used instead of size in this and other analyses because the log transformation smooths and normalizes the data, minimizing problems caused by errors in the variables (Reinganum, 1981). As Table 2 indicates, sixty

\section{Table 1}

\section{Average Monthly Returns by Neglect Categories 1976- 1981}

\begin{tabular}{lll}
\hline RCR1 & Ret* & $=0.011$ \\
$>8$ Analysts & Avg. No. of Analysts $=14.6$ \\
& Avg. Mkt. Value $=\$ 1,955.6^{* *}$ \\
& Avg. Beta & $=1.09$ \\
\hline & Ret & $=0.017$ \\
RCR2 & Avg. No. of Analysts $=5.1$ \\
$3-8$ Analysts & Avg. Mkt. Value $=\$ 366.2$ \\
& Avg. Beta & $=1.18$ \\
\hline & Ret & $=0.024$ \\
& Avg. No. of Analysts $=0.85$ \\
RCR3 & Avg. Mkt. Value $=\$ 123.3$ \\
<3 Analysts & Avg. Beta & $=1.22$ \\
\hline
\end{tabular}

- Average monthly return including dividends

** in millions 
Table 2

$N A_{t}=\gamma_{1} \beta_{t}+\gamma_{2}\left(\log \operatorname{Size}_{t}\right)$

\begin{tabular}{lccc}
\hline$R^{2}=0.6013$ & & & \\
Variable & Coef. & Std. Error & $t$-value \\
\hline Beta & -2.53 & 0.074 & 34.19 \\
L Size & 1.10 & 0.023 & 47.83 \\
\hline
\end{tabular}

per cent of the variance in the number of analysts across all stocks could be associated with fluctuations in beta and firm size, the former being significantly negatively correlated with analysts' attention and the latter being positively correlated.

The results of the tabular correction for size are presented in Table 3. Across the top of the Table the labels for the iso-size portfolios run from the smallest market value securities in SZGRS with capitalizations less than $\$ 100$ million to the largest market value securities in SZGRI with capitalizations greater than $\$ 500$ million. On the right hand side results for the mean-neglect portfolios are computed in the same manner as in Table 1. Portfolios along the bottom of the table are the mean-size analogies of these portfolios. 'Ret' signifies the average monthly returns from the equally weighted portfolios and 'ER' denotes the excess returns after risk adjustments for systematic risk.

Table 3

Returns Controlled for Beta and Size

\begin{tabular}{|c|c|c|c|c|c|c|c|c|}
\hline & \multicolumn{2}{|r|}{$\begin{array}{l}\text { SZGR3 } \\
\text { (small) }\end{array}$} & \multicolumn{2}{|r|}{$\begin{array}{c}S Z G R 2 \\
\text { (medium) }\end{array}$} & \multicolumn{2}{|r|}{$\begin{array}{c}\text { SZGR1 } \\
\text { (large) }\end{array}$} & \multicolumn{2}{|r|}{$\begin{array}{c}\text { MEAN } \\
R C R\end{array}$} \\
\hline $\begin{array}{l}\text { RCR 1 } \\
\text { (closely f }\end{array}$ & $\begin{array}{l}\text { RET } \\
\text { ER } \\
\text { ollowed }\end{array}$ & $\begin{array}{l}=-0.016 \\
=-0.025^{* *} \\
\text { d) }\end{array}$ & $\begin{array}{l}\text { RET } \\
\text { ER }\end{array}$ & $\begin{array}{l}=0.011^{* *} \\
=-0.002^{* *}\end{array}$ & $\begin{array}{l}\text { RET } \\
\text { ER }\end{array}$ & $\begin{array}{l}=0.011^{* *} \\
=-0.0009\end{array}$ & $\begin{array}{l}\text { RET } \\
\text { ER }\end{array}$ & $\begin{array}{l}=0.011^{* *} \\
=-0.0015^{*}\end{array}$ \\
\hline $\begin{array}{l}\text { RCR2 } \\
\text { (moderat }\end{array}$ & $\begin{array}{l}\text { RET } \\
\text { ER } \\
\text { ely foll }\end{array}$ & $\begin{array}{l}=0.011^{* *} \\
=-0.004^{* *} \\
\text { lowed) }\end{array}$ & $\begin{array}{l}\text { RET } \\
\text { ER }\end{array}$ & $\begin{array}{l}=0.018^{* *} \\
=\quad 0.04^{* *}\end{array}$ & $\begin{array}{l}\text { RET } \\
\text { ER }\end{array}$ & $\begin{array}{l}=0.017^{* *} \\
=\quad 0.005^{* *}\end{array}$ & $\begin{array}{l}\text { RET } \\
\text { ER }\end{array}$ & $\begin{array}{l}=0.017^{* *} \\
=\quad 0.003^{* *}\end{array}$ \\
\hline $\begin{array}{l}\text { RCR3 } \\
\text { (neglecte }\end{array}$ & $\begin{array}{l}\text { RET } \\
\text { ER } \\
\text { d) } \\
\end{array}$ & $\begin{array}{l}=0.024^{* *} \\
=\quad 0.011^{* *}\end{array}$ & $\begin{array}{l}\text { RET } \\
\text { ER }\end{array}$ & $\begin{array}{l}0.023^{* *} \\
0.012^{* *}\end{array}$ & $\begin{array}{l}\text { RET } \\
\text { ER }\end{array}$ & $\begin{array}{l}0.024^{* *} \\
0.013^{* *}\end{array}$ & $\begin{array}{l}\text { RET } \\
\text { ER }\end{array}$ & $\begin{array}{l}=\quad 0.024^{* *} \\
=\quad 0.011^{* *}\end{array}$ \\
\hline $\begin{array}{l}\text { MEAN } \\
\text { SIZE }\end{array}$ & $\begin{array}{l}\text { RET } \\
\text { ER }\end{array}$ & $\begin{array}{l}=0.022^{* *} \\
=\quad 0.008^{* *}\end{array}$ & $\begin{array}{l}\text { RET } \\
\text { ER }\end{array}$ & $\begin{array}{l}=0.018^{* *} \\
=0.005^{* *}\end{array}$ & $\begin{array}{l}\text { RET } \\
\text { ER }\end{array}$ & $\begin{array}{l}=0.013^{* *} \\
=0.001^{*}\end{array}$ & & \\
\hline
\end{tabular}

- Significant at the 90 percent level

** Significant at the 95 percent level 


\section{Table 3a \\ Two Way Factor Analysis of \\ Mean Excess Returns}

\begin{tabular}{lll}
\cline { 2 - 3 } & Neglect & Size \\
\cline { 2 - 3 }$F(2,4)$ & $7.6^{* *}$ & 2.7 \\
$F_{0.05}$ & 6.94 & 6.94 \\
\hline \multirow{2}{*}{$\begin{array}{l}\text { significant at the } 95 \\
\text { of confidence }\end{array}$}
\end{tabular}

First, it is apparent that both the neglected firm effect and the size effect survive risk adjustment. The neglected firm effect is evident from the difference in excess returns between the mean-neglect portfolios RCRI and RCR3, going from - 0.0015 to 0.011 per month on average. The size effect shows similar strength before controlling for neglect. Monthly excess returns go from a barely significant 0.001 in SZGRI to a highly significant 0.008 in SZGR3. Since size and neglect are correlated, the excess returns on the mean RCR and mean SZGR portfolios are similar.

In the interior cells of Table 3, we find, without exception that moving down the columns, increasing neglect is associated with both higher returns and higher excess returns. There is, therefore, evidence of a significant neglected firm effect even after controls are made for the size effect. By contrast, after controlling for neglect, the size effect largely disappears. In fact along the last two interior rows (RCR2 and RCR3) the size effect is consistently reversed; excess returns decline systematically with lower market value. Neglect, therefore, seems to be more systematically correlated than size, with excess returns.'

Evidence of the independence of neglect and size is also contained in the interior cells of Table 3. If size and neglect were too highly correlated for independent analysis, i.e. perfectly correlated, then the interior matrix would be largely confined to the diagonals (RCR1 - SZGR1, RCR2 - SZGR2, RCRJ SZGR3). All off diagonal elements would be empty. However, these off diagonal elements are not empty. Instead, they provide further evidence of the strength of neglect compared to size as an explanatory variable for excess returns. Comparing portfolio RCRI - SZGR3 with portfolio RCRJ - SZGRI we find that large neglected securities far outperform small highly researched stocks, with excess returns going from a highly significant 0.013 per month in RCRJ - SZGRI to a negative 0.025 per month in RCRI - SZGR3. 
Similar results are obtained when comparing portfolio RCRP - SZGR3 to RCR3 - SZGR2 and RCRI - SZGR2 to RCR2 - SZGR1. In every instance neglect is stronger than size in its apparent correlation with returns and excess returns.

In order to rigorously test the hypothesis that, $H_{o}$ : there is no difference in population mean excess returns among neglect categories and that, $H_{0}$ : there is no difference in population mean excess returns among size categories, we employ the $F$ statistic computed from a two factor analysis of variance (Lintner, 1965). Here we test for the independent explanatory power of neglect and size controlling for the other variable.

The results in Table 3a provide more rigorous proof that the neglected firm effect exists after controlling for size controls for neglect. The statistically significant $F$ statistic for neglect of 7.6 indicates that there is a significant difference among mean excess returns of the different RCR groups in all rows. However, the $F$ statistic for size is not statistically significant. The results of the Fama-Macbeth regressions shown in Table 4 are consistent with the results of the tabular analysis. The intercept of the pooled coefficients is insignificant, even at the ninety per cent level. Beta is positively related to returns with a coefficient of 0.0025 ; however, it is not statistically significant.

This result is similar to what Banz (1978) found using a similar methodology. The reason for Beta's insignificance is probably due to the fact that the number of sample portfolios, although sufficient for the statistical testing of neglect, is smaller than needed to bring out the significance of beta. The most relevant result in Table 4, however, is the relative predictive power of the 'neglected' and 'small firm effects'. MNA denotes the mean number of analysts covering stocks in each portfolio. As is evident from the standard

\section{Table 4}

\section{Pooled-Cross Sectional Regression}

\begin{tabular}{lccc}
\hline$R_{\mathrm{p}}=\delta_{0}+\delta_{1}($ MBeta $)+\delta_{2}(\mathrm{MNA})+\begin{array}{c}\boldsymbol{\delta}_{3}(\text { LMSIZE }) \\
\text { Mean }\end{array}$ \\
Variable & $N^{*}$ & Coef. & Std. Err. \\
\hline Intercept & 71 & 0.022 & 0.015 \\
M Beta & 71 & 0.0025 & 0.0044 \\
MNA & 71 & -0.0007 & 0.0003 \\
LMSIZE & 71 & -0.0005 & 0.0011 \\
\hline
\end{tabular}

- $N=71$ because one month of data is lost due to the fact that these are predictive regressions. No data is available in December 1975 to predict January 1976 returns. 
error, the number of analysts is significantly and negatively related to portfolio returns. Thus, the neglected firm effect is significantly present.

By contrast, the size effect is apparent, but insignificant after controlling for neglect. The variable LMSIZE is the natural log of the average market value of each portfolio. Although the average coefficient is negative, implying that smaller stock portfolios earn higher returns, the coefficient is insignificant. This result is very similar to that which is apparent from Table 3. While the neglected firm effect persists after controlling for size, the size effect is not statistically significant after controlling for neglect.

To ensure that the neglected firm effect is not an artifact of the January effect, the analysis was repeated with January returns eliminated from the sample; the results are shown in Tables 5, 5a and 6. The first result, apparent in Table 5, is that the size effect is substantially weakened by the elimination of January returns. Examining the Mean-SZGR portfolios, there is little or no evidence of a size effect with average returns going from 0.013 per month in SZGRI to 0.016 in SZGR2 and SZGR3. Excess returns show a similar reaction to decreasing market value, flattening out to 0.004 in SZGRP and 0.003 per month in SZGR3. These results are consistent with those reported by Reinganum (1981), Roll (1983) and Keim (1982). In general, approximately fifty percent of the excess returns of small capitalization stocks are found to occur in January. This is evident in this study as excess returns decline from 0.008 to 0.003 per month in SZGR3 with the exclusion of January's returns. (See Tables 3 and 5).

Along the column on the far right of Table 5 are the results for the Mean- RCR portfolios. Although the absolute magnitude of the neglected firm effect has been diminished with the exclusion of January returns there is still a strong relationship between returns, excess returns, and neglect. This is yet another 
Table 5

Returns Controlled for Beta, Size and 'January Effect'

\begin{tabular}{|c|c|c|c|c|c|c|}
\hline \multirow[b]{2}{*}{$\begin{array}{l}\text { RCR } 1 \\
\text { (closely fol }\end{array}$} & \multicolumn{2}{|c|}{$\begin{array}{l}\text { SZGR3 } \\
\text { (small) }\end{array}$} & \multicolumn{2}{|c|}{$\begin{array}{c}S Z G R 2 \\
\text { (medium) }\end{array}$} & \multirow{2}{*}{$\begin{array}{c}\begin{array}{c}\text { SZGR1 } \\
(\text { large) }\end{array} \\
\text { Ret }=0.011 * * \\
\mathrm{ER}=0.0009\end{array}$} & $\begin{array}{c}\text { MEAN } \\
R C R\end{array}$ \\
\hline & $\begin{aligned} & \text { Ret }= \\
& \text { ER }= \\
& \text { llowed) }\end{aligned}$ & $\begin{array}{l}-0.018 \\
-0.023^{*} \\
\end{array}$ & $\begin{array}{l}\text { Ret }= \\
\text { ER }=\end{array}$ & $\begin{array}{c}0.010 \\
-0.033^{* *}\end{array}$ & & $\begin{array}{l}\text { Ret }=0.01^{* *} \\
\text { ER }=-0.0016^{* *}\end{array}$ \\
\hline $\begin{array}{l}\text { RCR2 } \\
\text { (moderatel }\end{array}$ & $\begin{array}{l}\text { Ret }= \\
\text { ER }= \\
\text { ly follon }\end{array}$ & $\begin{array}{l}0.006^{* *} \\
0.007^{* *} \\
\text { ved) } \\
\end{array}$ & $\begin{array}{l}\text { Ret }= \\
\text { ER }=\end{array}$ & $\begin{array}{l}0.016^{* *} \\
0.003^{* *}\end{array}$ & $\begin{array}{l}\text { Ret }=0.017^{* *} \\
\text { ER }=0.005^{* *}\end{array}$ & $\begin{array}{l}\text { Ret }=0.014^{* *} \\
\text { ER }=0.001^{* *}\end{array}$ \\
\hline $\begin{array}{l}\text { RCR3 } \\
\text { (neglected) }\end{array}$ & $\begin{array}{l}\text { Ret }= \\
\text { ER }= \\
\end{array}$ & $\begin{array}{l}0.018^{* *} \\
0.005^{* *}\end{array}$ & $\begin{array}{l}\text { Ret }= \\
\mathbf{E R}=\end{array}$ & $\begin{array}{l}0.02^{* *} \\
0.009^{*}\end{array}$ & $\begin{array}{l}\text { Ret }=0.021^{* *} \\
\text { ER }=0.01^{*}\end{array}$ & $\begin{array}{l}\text { Ret }=0.019^{* *} \\
\text { ER }=0.007^{* *}\end{array}$ \\
\hline $\begin{array}{l}\text { Mean } \\
\text { SZGR }\end{array}$ & $\begin{array}{l}\text { Ret }= \\
\text { ER }=\end{array}$ & $\begin{array}{l}0.016^{* *} \\
0.003^{* *}\end{array}$ & $\begin{array}{l}\text { Ret }= \\
\text { ER }=\end{array}$ & $\begin{array}{l}0.016^{* *} \\
0.004^{* *}\end{array}$ & $\begin{array}{l}\text { Ret }=0.013^{* *} \\
\text { ER }=0.0009\end{array}$ & \\
\hline
\end{tabular}

- Significant at the 90 percent level

* Significant at the 95 percent level

Table 5a

Two Way Factor Analysis of

Mean Excess Returns

Controlling for January Effect

\begin{tabular}{lll}
\hline & Neglect & Size \\
\hline $\mathrm{F}(2,4)$ & $9.24^{* *}$ & 6.42 \\
$\mathrm{~F}_{0.05}$ & 6.94 & 6.94 \\
\hline
\end{tabular}

* Significant at the 95 percent level of confidence

piece of evidence which indicates that the neglected firm effect and the size effect are not identical.

The results from the size only and neglect only analysis are substantiated by the results found in the interior cells of Table 5. After controlling for neglect the size effect is, without exception, consistently and significantly reversed. Moving along any row, from SZGRI to SZGRS, returns and excess returns decline with firm size. Specifically, in RCRS, we can observe excess returns going from 0.01 per month on average in SZGRI to 0.005 in SZGRS.

Table 5a provides information similar to that presented in Table 3a. The F statistic for neglect indicates that there are still significant differences between the mean excess returns of the RCR 
portfolios after controlling for size. However, as in Table 3a, the size effect is not statistically significant. Although it is now close to significance with an F statistic of 6.41 (critical value is 6.94), the sign is now reversed and it is the reversed size effect that is approaching significance.

The impact of the January effect on both the neglected firm effect and the size effect was also tested using the Fama-Macbeth methodology. These results are found in Table 6. The intercept, although reduced in magnitude relative to the regressions including January returns, is still not significantly different from zero. Beta remains a poor predictor of portfolio returns with a positive but insignificant coefficient of 0.004 . The most interesting results, however, pertain to the coefficient of neglect and size.

\section{Table 6}

Pooled Cross Sectional Regression (Eliminating
January Returns)
$\mathrm{R}_{\mathrm{p}}=\delta_{0}+\delta_{1}$ (MBeta) $+\delta_{2}$ (MNA) $+\delta_{3}$ (LMSIZE)

\begin{tabular}{llcc}
\hline Variable & $N^{*}$ & Mean Coefficient & Standard Error \\
\hline Intercept & 66 & 0.0097 & 0.0133 \\
MBeta & 66 & 0.004 & 0.0046 \\
MNA & 66 & -0.0006 & 0.0002 \\
LMSIZE & 66 & 0.0003 & 0.001 \\
\hline
\end{tabular}

* There are 66 months of Data in this cross-sectional analysis. 72 months in the sample less six months of January data which are eliminated prior to the computation of the pooled coefficients.

The coefficient associated with the average number of analysts covering stocks within the portfolio (MNA) is stil1 significant and negative. This result is consistent with the tabular analysis of Table 5. The coefficient's magnitude was reduced from - 0.0007 to - 0.0006 when January's returns were eliminated from the analysis. The small reduction for the magnitude of the neglect coefficient implies that the neglected firm effect is not strongly correlated with the January effect.

By contrast, the size effect is both insignificant and its sign reversed. The coefficient associated with the log of the average size of stocks in the portfolios is 0.0003 as opposed to a coefficient of 0.0005 when January returns are included in the analysis (see Table 4). This result is also consistent with the tabular analysis pf Table 6: the size effect, being very dependent upon January returns, is no longer 
evident and any influence it has on returns apparently is reversed when both the neglected firm effect and the January effect are controlled for.

\section{Conclusion}

This study provides strong statistical evidence of an independent neglected firm effect. After segmenting the market sample into portfolios based on a security's level of analyst attention we come to two interesting conclusions. First, that the neglected firm effect is independent of, and in fact may dominate the small firm effect. Second, that the neglected firm effect is a more robust anomally than the size effect in that it persists after controlling for both the small firm effect and the January effect.

Since its discovery researchers have sought an explanation for the anamolous returns offered by small capitalization firms. The authors believe that the evidence herein provides a logical basis for this anomaly. The small firm effect is in fact a proxy for the neglected firm effect. Neglected firms offer excess returns due to their higher level of informational uncertainty. What remains is to find an empirically acceptable way to include this informational uncertainty into the risk-pricing mechanism.

Some progress has been made by incorporating the variance in analysts' forecasts into the beta risk coefficient (Strebel, 1983). It is not clear, however, to what extent this captures the full range of informational uncertainty associated with the lack of analysts' attention. Aswath Damadaran, for example, points out that scarce information may cause not only higher variance, but also less positive skewness and greater kurtosis in the return distribution (Damadaran, 1985). If so, the mean variance model may provide an inadequate representation of the relationship between the risk and return on neglected firms. What is needed is thorough, comparative testing of the ability of the new beta, incorporating analysts' forecasts, to explain the superior returns on neglected firms, relative to other measures of informational risk. Such research would assist in resolving the neglected firm and other return anomalies.

\section{Notes}

1. The mean monthly T-Bill return during the test period was 0.007 with a median of0.007. Based on the mean returns of the Wilshire 5000 value weighted index $(0,012$ per month) and the TBib, the average market risk premium was 0.005 per month or approximately six percent per year. This result is consistent with the risk premia found in other studies of longer periods (Ibbotson and Sinquefield, 1982). 
2. Since risk adjustment calculations and expected returns are carried out here in the context of the CAPM, use of the equally weighted index would itself capture most of the small firm effect. This is due to the fact that, in the equally weighted index, the numerous small capitalization stocks take on an abnormally high importance when determining market returns.

3. The Wilshire index was used here rather than the more narrow NYSE composite index to partially address Roll's critique of the use of narrow market indices. For tests of the Neglected Firm Effect employing more narrow indices see Arbel and Strebel (1982 and 1983).

4. Since the cutoff points on both the size and neglect dimensions were obtained independently, the number of stocks within each size-neglect cell varies widely. As a result, the mean returns reported on the bottom Tow and the extreme right-hand column of the table are not simple arithmetic, but weighted averages of the corresponding rows and columns. This procedure is methodologically similar to that employed by Reinganum (1981) to study the interaction between earnings yields and market value. For a breakdown of the average number of stocks in each cell, see the table below.

\begin{tabular}{lrrrc} 
& S2GR3 & S2GR2 & S2GR1 & Mean \\
\cline { 1 - 2 } RCR1 & 5 & 49 & 152 & 206 \\
RCR2 & 38 & 141 & 49 & 228 \\
RCR3 & 213 & 89 & 12 & 314 \\
Mean & 256 & 279 & 213 &
\end{tabular}

\section{References}

Arhel, A. and P. Strebel (1982), 'The Neglected and Small Firm Effects', Financial Review, Vol17, No. 4, 1982). (1983), 'Pay Attention to Neglected Firms', Journal of Portfolio Management, (Winter 1983), S. Carvell and P. Strebel (1983), 'Giraffes, Institutions and Neglected Firms', Financial Analysts Journal (1983). 
Ball, R. (1978), 'Anomalies in Relationship Between Securities Yields and Yield Surrogates', Journal of Financial Economics, Qune-Sept. 1978).

Banz, R.W. (1978), 'Limited Diversification and Market Equilibrium: An Empirical Analysis', PhD. Dissertation, University of Chicago, Chicago, IL, (1978). (1981), 'The Relationship Between Return and Market Value of Common Stocks', Journal of Financial Economics, (Vol. 9, 1981).

Barry Ch.B. and S. Brown (1984), 'Differential Information and the Small Firm Effect', Journal of Financial Economics (No. 13, 1984), pp. 283-294.

Basu, S. (1977), 'Investment Performance of Common Stocks in Relation to Their Price-Earnings Ratios: A Test of the Efficient Market Hypothesis', Journal of Finance, Qune 1977).

Bawa, V.S. (1975), 'Optimal Rules for Ordering Uncertain Prospects', Journal of Financial Economics, No. 2 (1975). (1976), 'Admissible Portfolios for All Individuals', Journal of Finance, No. 31 (1976).

Black, F. and M. Scholes (1974), 'The Effect of Dividends Yield and Dividend Policy on Common Stock Prices and Returns', Journal of Financial Economics, Vol. I (1974).

Brown, S.J. (1976), Optimal Portfolio Choice Under Uncertainty: A Bayesian Approach', Ph.D. Dissertation, University of Chicago: Chicago, IL (1976). (1977), ‘Estimation Risk and Capital Market Equilibrium', Bell Labs, Paper No. 87 (April 1977).

Copeland, T.E. andJ.F. Weston (1980), Financial Theory and Corporate Policy (Addison-Wesley, 1980).

Damadaran, A. (1985), 'Economic Events, Information Structure, and the Return Generating Process', Journal of Financial and Quantitative Analysis, Vol. 20, No.4 (1985).

Dimson, E. (1979), 'Risk Measurement When Shares Are Subject to Infrequent Strategy', Journal of Financial Economics, Vol. 7 (1979) pp. 197- 226.

Fama, E.F. (1976), Foundations of Finance (Basic Books, 1976). and J.D. MacBeth (1973), 'Risk, Return, and Equilibrium: Some Empirical Tests', Journal of Political Economy, No. 71 (1973).

Ibbotson, R.G. and R.A. Sinquefield (1982), Stocks, Bonds, Bills and Inflation: The Past and Future. The Financial Analysts Research Foundation, Charlottesville, VA (1982). 
Johnston, J. (1973), Econometric Methods, 2nd edition (John Wiley, 1973).

Kalymon, B.A. (1971), 'Estimation Risk in the Portfolio Selection Model', Journal of Financial and Quantitative Analysis (January 1971).

Kiem, D.B. (1982), 'Size Related Anomalies and Stock Return Seasonability: Further Empirical Evidence', Graduate School of Business, University of Chicago, WP No. 72 Oune 1982).

Klein, R.W. and V.S. Bawa (1976), 'The Effect of Estimation Risk on Optimal Portfolio Choice', Journal of Financial Economics, Vol. 5 (1976).

Kraus, A. and R.H. Litzenberger (1976), 'Skewness Preference and the Valuation of Risky Assets', Journal of Finance (1976).

Lintner, J. (1965), 'The Valuation of Risk Assets and the Selection of Risk Investments in Stock Portfolios and Capital Budgets', Review of Economics and Statistics (Feb. 1965).

Litzenberger, R.H. and K. Ramaswamy (1979), 'The Effect of Personal Taxes and Dividends on Capital Asset Prices: Theory and Empirical Evidence', Journal of Economic Theory, Vol. III (1979).

Merton, R. (1971), 'Optimum Consumption and Portfolio Rules in a Continuous Time Model', Journal of Economic Theory, Vol. III (1979). (1973), 'An Intertemporal Capital Asset Pricing Model', Econometrica, Vol. 16 (1973).

Mossin, J. (1966), 'Equilibrium in a Capital Asset Market', Econometrica, Vol. 35 (1966).

Miller, P.F. and E.R. Widmann (1966), 'Price Performance Outlook for High and Low PIE', Commercial \& Financial Chronicle, (Stock and Bond Issue, Sept. 1966).

Nicholson, R. (1968), 'Price Ratios in Relation to Investment Results', Financial Analysts Journal (Feb. 1968).

Reinganum, M. R. (1981), 'Misspecification of Capital Asset Pricing: Empirical Anomalies Based on Earnings Yields and Market Values', Journal of Financial Economics, (Vol. 9, 1981). (1982), 'A Direct Test of Roll's Conjecture on the Firm Size Effect', Journal of Finance, (Vol. 37, 1982). 
Roll, R. (1977), 'A Critique of the Asset Pricing Theory's Tests', Journal of Financial Economics,

(Vol. 4, 1977). (1981), 'A Possible Explanation of the Small Firm Effect', Journal of Finance, Vol. 36(1981). (1983), 'Vas ist das', Journal of Portfolio Management (Winter 1983).

Sharpe, W.F. (1964), 'Capital Asset Prices: A Theory of Market Equilibrium under Conditions of Risk', Journal of Finance, Vol. 29 (1964).

Strebel, P.J. (1983), 'Analysts' Forecasts in the Capital Asset Pricing Model', Economics Letters, Vol. 13 (1983), pp. 223-229.

Theil, H. (1971), Principles of Econometrics (Wiley, 1971).

Treynor, J.L. (1961), 'Toward a Theory of Market Value of Risky Assets', Unpublished Memorandum (1961).

Vasice-k, O.A. (1983), 'A Note on Using Cross-sectional Information in Bayesian Estimation of Security Betas', Journal of Finance, (Vol. 38, 1983).

Von Neumann J. and O. Morgenstern (1967), Theory of Games and Economic Behavior (Wiley, 1967).

Williams, J.P. (1970), Investment - New Analytic Techniques (Praeger, 1970).

Zellner, A. (1971), An Introduction to Bayesian Inference in Econometrics (Wiley, 1971). 